\title{
Effect of titanium surface roughness on human bone marrow cell proliferation and differentiation. An experimental study ${ }^{1}$
}

\author{
Efeito da rugosidade de superfície de discos de titânio sobre a proliferação e diferenciação de \\ células de medula óssea humana. Estudo experimental
}

\author{
Taís Somacal Novaes Silva ${ }^{\mathrm{I}}$, Denise Cantarelli Machado"I, Christian Viezzer ${ }^{\mathrm{III}}$, Aurelício Novaes Silva Júnior ${ }^{\mathrm{IV}}$, Marília Gerhardt \\ de Oliveira ${ }^{\mathrm{v}}$ \\ I Fellow PhD Degree, Department of Oral and Maxillofacial Surgery (OMFS), School of Dentistry, PUCRS, Porto Alegre-RS, Brazil. \\ ${ }^{\text {II }} \mathrm{PhD}$, Full Professor, Department of Cellular Biology and Respiratory Diseases, School of Dentistry, PUCRS, Porto Alegre-RS, Brazil. \\ III Fellow Master Degree, Department of Cellular Biology and Respiratory Diseases, School of Dentistry, PUCRS, Porto Alegre-RS, Brazil. \\ ${ }^{\text {IV }} \mathrm{PhD}$, Full Professor, OMFS, School of Dentistry, Lutheran University of Brazil (ULBRA), Canoas-RS, Brazil. \\ ${ }^{v}$ PhD, Full Professor, OMFS, School of Dentistry, PUCRS, Porto Alegre-RS, Brazil.
}

\begin{abstract}
Purpose: To assess the proliferation and differentiation of human bone marrow-derived cells cultured on titanium surfaces with different roughness characteristics. Methods: Cells obtained from the iliac crest of an adult human donor were routinely processed and cultured on titanium surfaces of varying roughness, according to their preparation method: polishing only (smooth surface) and polishing followed by etching with $\mathrm{HF} / \mathrm{HNO}_{3}$ for 15 and 30 minutes (rough surfaces). Surfaces were assessed using scanning electronic microscopy and profilometry. Results: Titanium disks etched with acid for 15 minutes allowed greater cell proliferation in all culture periods. The level of osteopontin and osteocalcin expression was increased in both acid-etched groups, which indicates an advanced stage of differentiation of cells into osteoblasts. Conclusions: Increased surface roughness accelerates the differentiation of undifferentiated mesenchymal cells into osteogenic lineage cells, but does not necessarily favor cell proliferation. An intermediate surface roughness of $0.5 \mu \mathrm{m}$ (acid etching for 15 minutes) favors both initial and final cell responses.
\end{abstract}

Key words: Dental Implantation. Titanium. Cell Proliferation. Stem Cells.

\section{RESUMO}

Objetivo: Avaliar a proliferação e diferenciação de células derivadas da medula óssea humana sobre superfícies de titânio com diferentes rugosidades de superfície. Métodos: Células obtidas da crista ilíaca de um doador humano adulto foram rotineiramente processadas e cultivadas sobre superfícies de titânio preparadas através de polimento apenas, ou polimento seguido de condicionamento com $\mathrm{HF} / \mathrm{HNO}_{3}$ por 15 e 30 minutos, para produzir superfícies com rugosidades variadas, conforme determinado por Microscopia Eletrônica de Varredura e perfilometria. Resultados: Discos de titânio condicionados com ácido por 15 minutos permitiram maior proliferação celular em todos os períodos de cultura. O nível de expressão das proteínas osteopontina e osteocalcina estava aumentado em ambos os grupos condicionados com ácido, indicando que as células estavam comprometidas com o fenótipo osteogênico. Conclusões: $\mathrm{O}$ aumento na rugosidade de superfície acelera a diferenciação de células mesenquimais indiferenciadas em células de linhagem osteogênica, mas não necessariamente favorece a proliferação celular. Uma superfície com rugosidade intermediária de $0,5 \mu \mathrm{m}$ (condicionada com ácido por 15 minutos) favorece tanto as respostas celulares iniciais quanto as finais.

Descritores: Implante Dentário. Titânio. Proliferação de Células. Células-Tronco.

${ }^{1}$ Research performed at the Institute of Biomedical Research, Sao Lucas Hospital, Pontifical Catholic University of Rio Grande do Sul (PUCRS), Brazil.

\section{Introduction}

The establishment of clinical and experimental criteria for achieving osseointegration allowed the scientific community to change its focus and start seeking alternatives to enhance the quality and speed of the osseointegration process. Studies in the field of implantology have aimed at making osseointegrated implants rapidly available for clinical use, in an attempt to reduce or even eliminate the load-free healing period recommended in the research protocol established by the Götenborg-Sweden Group.

Many doubts persist with regard to the interaction between bone tissue and implant surface. However, at present, it is known that the initial events that take place at the bone-implant interface determine the success or failure of dental implants ${ }^{1}$. 
Several factors interfere with the osseointegration process: planning and selection of the most adequate surgical technique, implant design, and implant biocompatibility, which seems to be determined not only by chemical properties but also by surface properties $^{2}$.

The effects of surface topography on tissue response in vitro and in vivo have been extensively studied over the last decade, and no consensus has been reached. Several authors have reported an association between increased implant surface roughness (as a result of specific texturization techniques) and improved cell adhesion and proliferation findings ${ }^{3-7}$. Other studies, however, suggest that increased surface roughness is not a determinant factor for initial cell response $\mathrm{e}^{8-12}$. Finally, an in vitro study has suggested that osteoblasts show a preference for surfaces with a high degree of microroughness (mean roughness of approximately $0.5 \mu \mathrm{m})^{1}$.

The aims of this study were to characterize the topography of titanium disk surfaces submitted to polishing and to HF/ $\mathrm{HNO}_{3}$-etching for different periods of time, as well as to assess the proliferation and differentiation of human bone marrow-derived cells cultured on these surfaces. Assessment was carried out using quantitative analysis of cell proliferation and detection of osteospecific markers (osteopontin and osteocalcin) to confirm the presence of osteogenic lineage cells.

\section{Methods}

Titanium disks. Disks were made from a bar of $99 \%$ pure, grade II, commercially available titanium (Ticp), measuring $15 \mathrm{~mm}$ in diameter and $1 \mathrm{~mm}$ in thickness. They were processed by mechanical polishing under water irrigation using abrasive papers (SiC), a metal polishing cloth, and a titanium polishing cloth. Three specific surface topographies were prepared: surfaces submitted to polishing only, as detailed above (aiming at a smooth surface); surfaces submitted to polishing plus etching with $0.8 \% \mathrm{HF}, 13 \% \mathrm{HNO}_{3}$ solution for 15 minutes; and surfaces submitted to polishing plus etching (with the same solution) for 30 minutes. After surface preparation, all samples were cleaned in an ultrasound bath and autoclaved at $121{ }^{\circ} \mathrm{C}$ for 15 minutes.

Surface polishing regularity was assessed using scanning electronic microscopy (SEM), and parameters such as mean roughness $(\mathrm{Ra})$ and maximum roughness $(\mathrm{Rt})$, which is defined as the sum of the highest peak with the lowest valley within the measurement area, were measured with a profilometer. To gauge the roughness of disks, five areas were assessed in two disks randomly selected from each group.

Human bone marrow cell culture. Human bone marrow cells were obtained from a 45-year old patient in good physiological state admitted to the Oral and Maxillofacial Surgery and Traumatology Unite, São Lucas Hospital, Pontifical Catholic University of Rio Grande do Sul (PUCRS), for atresic maxilla reconstruction surgery using autogenous iliac crest bone graft.

Purified bone marrow cells were suspended in a Dulbecco's modified Eagle medium (DMEM), supplemented with $10 \%$ bovine fetal serum, $100 \mathrm{U} / \mathrm{ml}$ penicillin, $100 \mu \mathrm{g} / \mathrm{ml}$ streptomycin, and $50 \mu \mathrm{g} / \mathrm{ml}$ gentamycin, and counted. A new culture medium was then added to adjust cell concentration, composed of $40 \mu \mathrm{g}$ of BMP-4 per $\mathrm{ml}$ of DMEM. The suspension was added to previously prepared 24-well plates containing the titanium disks in aliquots of $500 \mu \mathrm{l}$ with a density of $0.5 \times 10^{5}$ cells per milliliter, counted in a hemocytometer. Finally, cultures were incubated and kept in a humidified oven at $37^{\circ} \mathrm{C}$ containing $5 \%$ of $\mathrm{CO}_{2}$.

Group information. Titanium disks were divided into three different groups of eight disks each, according to the treatment received, as follows: smooth group, polishing only; roughness 2 group, polishing plus $\mathrm{HF} / \mathrm{HNO}_{3}$ etching for 15 minutes; and roughness 3 group, polishing plus $\mathrm{HF} / \mathrm{HNO}_{3}$ etching for 30 minutes.

Cell proliferation. For the analysis of cell proliferation, the nuclei of cells present in each biosystem (in all groups) were stained with propidium iodide at 3, 7, 14 and 21 days after culture. After staining, disks were removed from the plate and placed on a slide for cell analysis and observation using an optic microscope and ultraviolet light.

For a precise determination of the number of cells, the biosystems were analyzed and randomly micrographed (twelve micrographs per surface) under an Axiolab optic microscope equipped with ultraviolet light, at a 50x magnification. Afterwards, micrographs were digitized by an image processing system to a standard size $(27 \times 18 \mathrm{~cm})$, over which a grid with standardized squares $(2.5 \times 3.25 \mathrm{~cm})$ was traced, simulating a hemocytometer. The program used to display the image on the computer monitor was Microsoft Powerpoint ${ }^{\circledR}$ version 2000.

Cell differentiation. Osteocalcin and osteopontin mRNA expression was detected by complete RNA extraction followed by reverse transcription reaction and polymerase chain reaction (PCR). Specific oligonucleotide initiators were used for each of the proteins. PCR products were submitted to horizontal electrophoresis in $2 \%$ agarous gel with TAE buffer containing ethidium bromide and visualized under ultraviolet light.

Statistical analysis. The non-parametric Kruskal-Wallis test was used to compare different groups and observation periods, as well as to assess the number of cells adhering to disks. The Statistical Package for the Social Sciences (SPSS) version 10.0 was used to process and analyze results.

This research project was conducted after being approved by the Scientific and Ethics Committee of the School of Dentistry at PUCRS and by the Research Ethics Committee at PUCRS. The study is in accordance with items III.3.i and III.3.t of the Brazilian Guidelines and Norms for Research involving Humans.

\section{Results}

Characterization of the titanium disk surface topography

Measurement of Ra and Rt parameters showed that HF/ $\mathrm{HNO}_{3}$-etching for 15 and 30 minutes produced disks with different surface topographies. According to the analysis of variance (ANOVA) and the Tukey multiple comparison test, Ra and Rt parameters were significantly different between the three groups $(\mathrm{p}=0.01)$ (Table 1).

SEM revealed that surfaces submitted to acid-etching for 15 minutes presented a more homogenous morphology, with groove-like depressions, while surfaces treated with acid for 30 minutes presented a rougher appearance, with many irregular projections (Figure 1). The microscopic findings of the smooth surface confirmed its polished appearance. 
TABLE 1 - Ra and Rt parameters in titanium disk groups*

\begin{tabular}{lcccccc}
\hline & \multicolumn{3}{c}{ Ra } & & \multicolumn{3}{c}{ Rt } \\
\cline { 2 - 6 } & \multicolumn{3}{c}{ Standard } & & & Standard \\
Group & Average & deviation & $\mathrm{p}$ & Average & deviation & $\mathrm{p}$ \\
\hline Smooth & $0.15^{\mathrm{A}}$ & 0.02 & $0.01^{\dagger}$ & $1.17^{\mathrm{A}}$ & 0.16 & $0.01^{\dagger}$ \\
Roughness 2 & $0.50^{\mathrm{B}}$ & 0.07 & & $4.49^{\mathrm{B}}$ & 0.78 & \\
Roughness 3 & $0.77^{\mathrm{C}}$ & 0.05 & & $6.58^{\mathrm{C}}$ & 0.66 & \\
\hline
\end{tabular}

* Figures followed by the same letter are not statistically different $\uparrow$ Significant $(\mathrm{p}<0.05)$

Source: Research data from PUCRS, 2004.

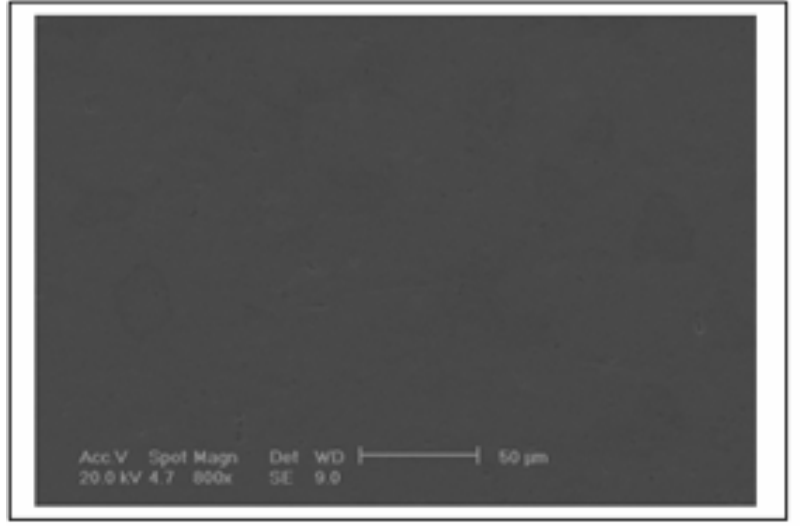

$1 \mathrm{~A}$

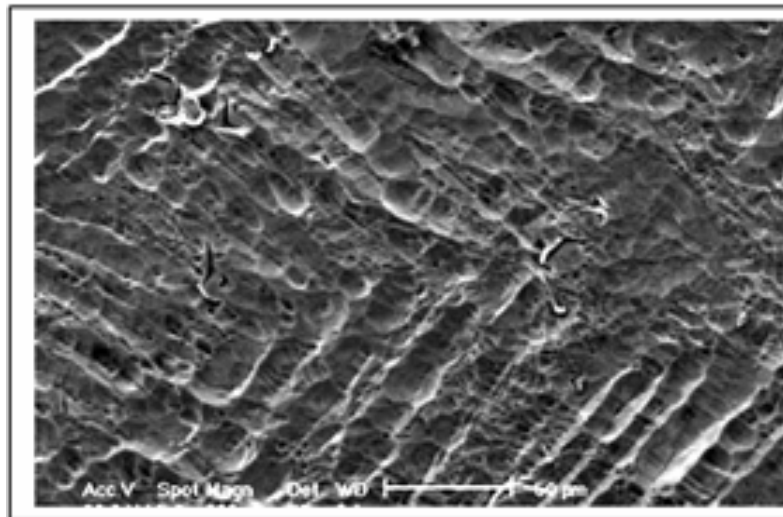

$1 \mathrm{~B}$

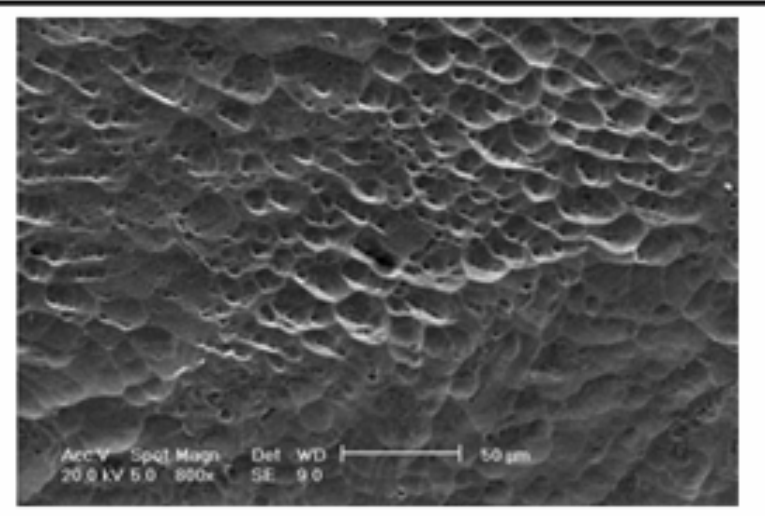

$1 \mathrm{C}$

FIGURE 1 - Scanning electron microscopy of titanium disk surfaces (scale and magnification: $50 \mu \mathrm{m}, 800 \mathrm{x})$. A) Smooth surface; B) $\mathrm{HF} / \mathrm{HNO}_{3}$ - etched surface (15 minutes); C) $\mathrm{HF} / \mathrm{HNO}_{3}$ - etched surface (30 minutes)

\section{Cell proliferation analysis}

The analysis of cell proliferation findings with the Kruskal-Wallis test revealed differences between the groups. At 3 days after culture, the smooth $(\mathrm{Ra}=0.15 \mu \mathrm{m})$ and roughness 3 $(\mathrm{Ra}=0.77 \mu \mathrm{m})$ groups presented lower proliferation values when compared to the roughness 2 group $(\mathrm{Ra}=0.50 \mu \mathrm{m})(\mathrm{p}=0.01)$. Cell proliferation analysis at 7 and 14 days after culture did not show statistically significant differences between the groups, although cells cultured on disks with intermediate roughness (roughness 2 group) presented improved proliferation (Table 2).

\section{Osteopontin and osteocalcin expression}

Osteopontin expression was determined by indirect detection of osteopontin mRNA by reverse transcription and cDNA synthesis at 3, 7, 14 and 21 days after culture. A greater expression was observed in cells cultured on disks with a roughness index between $0.50 \mu \mathrm{m}$ and $0.77 \mu \mathrm{m}$ (roughness 2 and roughness 3 groups), on days 3, 7 and 14 (Figure 2).

Osteocalcin expression was greater in later assessment periods (14 and 21 days), and in cells cultured on disks with a roughness index between $0.50 \mu \mathrm{m}$ and $0.77 \mu \mathrm{m}$ (roughness 2 and roughness 3 groups), especially at 14 days after culture (Figure 3 ). 
TABLE 2 - Number of cells adhered to titanium disks in each group at different culture periods*

\begin{tabular}{lcccc}
\hline Culture periods & $\mathrm{n}$ & Average & Standard deviation & $\mathrm{p}$ \\
\hline 3 days & 14 & $1.50^{\mathrm{A}}$ & 1.40 & $0.01^{\dagger}$ \\
Smooth & 14 & $12.86^{\mathrm{B}}$ & 4.97 & \\
Roughness 2 & 14 & $1.29^{\mathrm{A}}$ & 1.07 & \\
Roughness 3 & & & & \\
7 days & 14 & 4.50 & 3.82 & \\
Smooth & 14 & 6.79 & 3.96 & \\
Roughness 2 & 14 & 4.36 & 3.18 & \\
Roughness 3 & & & 3.65 & 0.46 (ns) \\
14 days & 14 & 4.64 & 3.62 & \\
Smooth & 14 & 5.79 & 2.16 & \\
Roughness 2 & 14 & 3.93 & & \\
Roughness 3 & & & & \\
\hline
\end{tabular}

* Figures followed by the same letter are not statistically different $\uparrow$ Significant $(\mathrm{p}<0.05)$

Source: Research data from PUCRS, 2004.

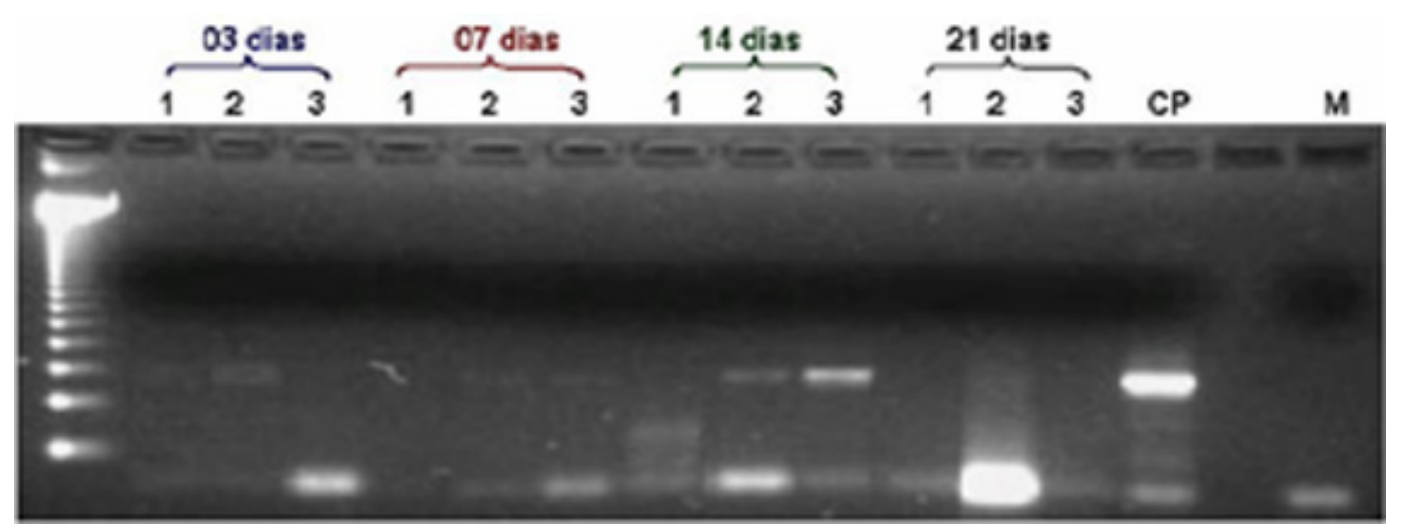

FIGURE 2 - Polymerase chain reaction of human bone marrow cells for osteopontin. Culture periods of 3, 7 , 14 and 21 days. Column 1 = smooth group; Column 2 = roughness 2 group; Column 3 = roughness 3 group; PC $=$ positive control; $\mathrm{M}=$ weight molecular marker of $123 \mathrm{pb}$ 


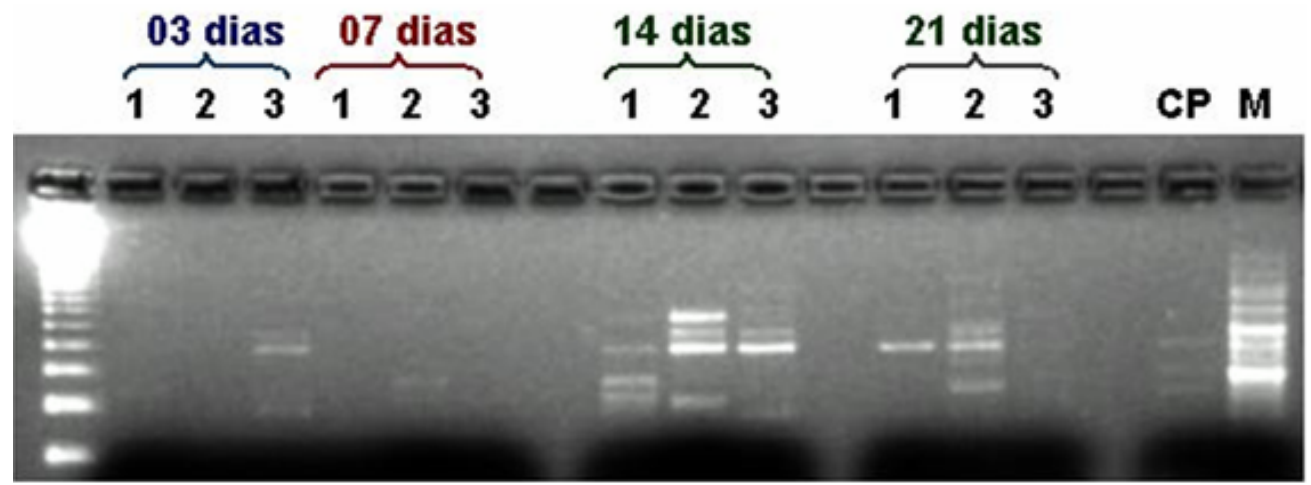

FIGURE 3 - Polymerase chain reaction of human bone marrow cells for osteocalcin. Culture periods of $3,7,14$ and 21 days. Column $1=$ smooth group; Column $2=$ roughness 2 group; Column $3=$ roughness 3 group; $\mathrm{PC}=$ positive control; $\mathrm{M}=$ weight molecular marker of $123 \mathrm{pb}$
Some in vitro studies have found an association between increased surface roughness and improved cell proliferation findings ${ }^{18}$. In the present study, however, a small cell proliferation index was observed on surfaces with greater roughness when compared with less rough surfaces. Our results showed a greater number of cells in all culture periods on surfaces with a roughness of $0.50 \mu \mathrm{m}$ (roughness 2 group, exposed to acid for $15 \mathrm{~min}$ ), thus corroborating the findings of Anselme ${ }^{1}$, Keller et al. ${ }^{4}$, and Isa et al. ${ }^{19}$, who suggested that a high degree of microroughness would favor initial cell responses of adhesion and proliferation.

Although the degree of cell proliferation was lower in rougher surfaces $(\mathrm{Ra}=0.77 \mu \mathrm{m})$, there was a greater expression of osteocalcin and osteopontin in these groups when compared to the smooth surface group. Possibly, the roughness may have favored the differentiation of adhered cells into osteogenic lineage cells, in spite of the low findings for cell proliferation. Similar results were found by Rosa and Beloti ${ }^{20}$; these authors compared surfaces with different levels of roughness obtained by the airborne particle abrasion process and found an association of increased alkaline phosphatase activity and total protein content with lower degrees of cell proliferation.

Some authors, such as Chou et al. ${ }^{21}$ and Jayaraman et al. ${ }^{10}$, assessed surface topography of titanium disks in relation to the morphology of cells and suggested that on grooved surfaces, cells acquired a more elongated and polarized morphology. This finding would be related to a greater protein synthesis by these cells, consequently favoring cell adhesion, proliferation and differentiation. Cell morphology may be related to improved cell proliferation findings observed in cultures carried out on titanium disks with a roughness of $0.50 \mu \mathrm{m}$ (grooved and regular appearance).

In terms of osteopontin expression, which was observed since the initial periods in cells cultured on titanium disks with a roughness of $0.50 \mu \mathrm{m}$ and $0.77 \mu \mathrm{m}$, our results corroborate the analyses carried out by Aubin ${ }^{22}$, who detected this marker in precursor cells at relatively early stages of differentiation.

Osteocalcin, in its turn, is currently considered to be the most specific osteoblastic marker, and is expressed at later stages of the differentiation process: it is undetectable in pre-osteoblasts, but can be found abundantly in post-mitotic and mature osteoblasts $^{22}$. Considering these data, it is possible to state that our acid-etched cells (roughness 2 and roughness 3 groups) were at advanced stages of differentiation on days 14 and 21 of the experiment.

A possible limitation of the present study refers to the difficulty in comparing our results with other studies available in the literature, due to the lack of characterization of the surfaces tested and of knowledge about the cell and tissue reactions obtained with different surface treatment options. of osteopontin and osteocalcin in cultures assessed at different time periods. 


\section{Conclusions}

The results obtained in this study suggest that rough surfaces submitted to acid-etching favor undifferentiated mesenchymal cell differentiation into osteogenic lineage cells when compared with smooth surfaces.

In our analysis, surfaces submitted to acid-etching for 15 minutes, with a mean roughness of $0.50 \mu \mathrm{m}$, were associated with better cell proliferation and differentiation findings.

\section{References}

1. Anselme K. Osteoblast adhesion on biomaterials. Biomaterials. 2000;21:667-81.

2. Bastos I, Vanzillotta P, Soares G. Caracterização morfológica e topográfica da superfície de implantes dentários. Rev Bras Odontol. 2003;60:47-50.

3. Bowers KT, Keller JC, Randolph BA, Wick DG, Michaels CM. Optimization of surface micromorphology for enhanced osteoblast responses in vitro. Int J Oral Maxillofac Implants. 1992;7:302-10.

4. Keller JC, Schneider GB, Stanford CM, Kellogg B. Effects of implant microtopography on osteoblast cell attachment. Implant Dent. 2003;12:175-9.

5. Ozawa S, Kasugai S. Evaluation of implant materials (hydroxyapatite, glass-ceramics, titanium) in rat bone marrow stromal cell culture. Biomaterials. 1996;17:23-9.

6. Maekawa K, Yoshida Y, Mine A, Fujisawa T, Van Meerbeek B, Suzuki $\mathrm{K}$, Kuboki T. Chemical interaction of polyphosphoric acid with titanium and its effect on human bone marrow derived mesenchymal stem cell behaviour. J Biomed Mater Res A. 2007;82:195-200.

7. Marinucci L, Balloni S, Becchetti E, Belcastro S, Guerra M, Calvitti M, Lilli C, Calvi EM, Locci P. Effect of titanium surface roughness on human osteoblast proliferation and gene expression in vitro. Int J Oral Maxillofac Implants. 2006;21:719-25.

8. Boyan B, Batzer R, Kieswetter K, Liu Y, Cochran DL, Szmuckler Moncler S, Dean DD, Schwartz Z. Titanium surface roughness alters responsiveness of MG63 osteoblast-like cells to $1 \alpha, 25-(\mathrm{OH})_{2} \mathrm{D}_{3}$. J Biomed Mater Res. 1998;29:77-85.

9. Guizzardi S, Galli C, Martini D, Belletti S, Tinti A, Raspanti M, Taddei P, Ruggeri A, Scandroglio R. Different titanium surface treatment influences human mandibular osteoblast response. J Periodontol. 2004; $75: 273-82$.
10. Jayaraman M, Meyer U, Bühner M, Joos U, Wiesmann HP. Influence of titanium surfaces on attachment of osteoblast-like cells in vitro. Biomaterials. 2004,25:625-31.

11. Kieswetter K, Schwartz Z, Hummert TW, Cochran DL, Simpson J, Dean DD, Boyan BD. Surface roughness modulates the local production of growth factors and cytokynes by osteoblast-like MG-63 cells. J Biomed Mater Res. 1996;32:55-63.

12. Martin JY, Schwartz Z, Hummert TW, Schraub DM, Simpson J, Lankford J Jr, Dean DD, Cochran DL, Boyan BD. Effect of titanium surface roughness on proliferation, differentiation, and protein synthesis of human osteoblast-like cells (MG63). J Biomed Mater Res. 1995;29:389-401.

13. Diniz M, Sader M, Soares G. Superfície de titânio modificada por jateamento mecânico e/ou tratamento ácido. Rev Bras Odontol. 2001;58:135-8.

14. Wieland M, Sittig C, Brunette DM, Textor M, Spencer ND. Measurement and evaluation of the chemical composition and topography of titanium implant surfaces. In: Davies JE. Bone engineering. Squared Inc; 2000. p.163-82.

15. Pittenger MF, Mackay AM, Beck SC, Jaiswal RK, Douglas R, Mosca JD, Moorman MA, Simonetti DW, Craig S, Marshak DR. Multilineage potential of adult human mesenchymal stem cells. Science. 1999;284:143-6. 16. Katagiri T, Takahashi N. Regulatory mechanism of osteoblast and osteoclast differentiation. Oral Dis. 2002;8:147-59.

17. Shimizu K, Yoshikawa H, Takaoka K. Local effects of bone morphogenetic protein-4 on skeletal tissues. Clin Orthop Relat Res. 1995;318:243-50. 18. Mustafa K, Wroblewski J, Lopez BS, Wennerberg A, Hultenby K, Arvidson K. Determining optimal surface roughness of TiO2 blasted titanium implant material for attachment, proliferation and differentiation of cells derived from human mandibular alveolar bone. Clin Oral Implants Res. 2001;12:515-25.

19. Isa ZM, Schneider GB, Zaharias R, Seabold D, Stanford CM. Effects of fluoride-modified titanium surfaces on osteoblast proliferation and gene expression. Int J Oral Maxillofac Implants. 2006;21:203-11.

20. Rosa A, Beloti M. Effect of cpTi surface roughness on human bone marrow cell attachment, proliferation, and differentiation. Braz Dent J. 2003; 14:16-21.

21. Chou L, Firth JD, Uitto V-J, Brunette DM. Substratum surface topography alters cell shape and regulates fibronectin mRNA level, mRNA stability, secretion and assembly in human fibroblasts. J Cell Sci. 1995;108:1563-73.

22. Aubin JE. Advances in osteoblast lineage. Biochem Cell Biol. 1998;76:899-910.

Conflict of interest: none Financial source: CAPES

\section{Correspondence:}

Dr. Taís Somacal Novaes Silva

Av. Wenceslau Escobar 945/315 - Bloco E

91900-000 Porto Alegre - RS Brazil

Phone/Fax: (55 51)3225-2521

tais.somacal@hotmail.com

Received: December 10, 2008

Review: February 11, 2009

Accepted: March 18, 2009

\section{How to cite this article}

Silva TSN, Machado DC, Viezzer C, Silva Júnior NA, Oliveira MG. Effect of titanium surface roughness on human bone marrow cell proliferation and differentiation. An experimental study. Acta Cir Bras. [serial on the Internet] 2009 May-Jun;24(3). Available from URL: http://www.scielo.br/acb 